\title{
Talent Management in the Public Sector
}

\author{
Tatjana Kozjek \\ University of Ljubljana, Faculty of Public Administration, Slovenia \\ tatjana.kozjek@fu.uni-lj.si \\ https://orcid.org/0000-0002-5626-8319 \\ Valentina Franca \\ University of Ljubljana, Faculty of Public Administration, Slovenia \\ valentina.franca@fu.uni-lj.si \\ https://orcid.org/0000-0002-9220-2077
}

Received: 14. 4. 2020

Accepted: 22. 10. 2020

\section{ABSTRACT}

Over the past decade, researchers and human-resource managers, particularly in larger private sector organisations, have shown an increased interest in talent management, while this issue has been overlooked in the public sector. The purpose of this paper is to present the literature review about talent management in the public sector and to show how the existing legislation allows the creation of a talent management system for Slovenian public sector organisations. The main methodological approach used was qualitative research with document analysis. The paper sought answers to three research questions: (How) are talented employees treated differently from other employees? What types of models or practices in the field of talent management are applied in European countries? What are the legal limitations in the field of civil servant talent management in Slovenia? The literature review shows that organisations that are aware of the importance and contribution to the ultimate organisational objectives treat talented employees differently from other employees in the organisation. Models or practices in the field of talent management vary widely among different European countries. The limitations in Slovenia are strict observance of the principle of equality and thus equal opportunities for inclusion in the system of talented civil servants with limited reward opportunities and, consequently, for the promotion of civil servants. In order to enable good practices in Slovenia, a change of the legal framework is necessary.

Keywords: civil servant, human resource management, employee motivation, public sector, remuneration, talent management 


\section{Introduction}

Although talent management is a relatively new concept in the field of human resource management, it is becoming increasingly important in practice and research. In defining the concept of talent management, literature often emphasises the role of talent in order to achieve performance, profit, and sustainable competitive advantage of the organisation (Collings, 2014); moreover, research analysing the field from the point of view of organisational behaviour is increasing (Björkman et al., 2013; Dries, 2013b; Meyers, van Woerkom and Dries, 2013; Tansley and Tietze, 2013). The authors mainly focused on the specificities of talent management in the private sector, and less on the position of civil servants. This is, in part, understandable, since the regulation enables enhanced possibilities for arrangements in the private sector compared with the public sector, which must follow strict rules on the payment of performance bonuses and other rewards to civil servants because of budgetary funding.

The purpose of this paper is to present the literature review about the importance of talent management in public sector and to show how the existing legislation allows creation of the talent management system for Slovenian public sector organisations. The paper first outlines the definitions of the concept of talent management, and further highlights the specificities and approaches in the field of talent management in the public sector. Specific focus is given to the legal aspect of talent management in public administration in Slovenia. Recommendations for the introduction of a talent management system in public administration in Slovenia based on the literature review of the foreign scientific literature, sources and the study of the existing legislation.

The contribution of the paper is to show the importance of talent management in the public sector and talent management systems in developed EU countries and encourage the legislators to pay attention to the problem of talent management in the Slovenian public sector and to make changes in this field.

\section{Methodological approach and research questions}

The main methodological approach that was used was the literature review and qualitative research with a document study. To show different definitions of a talent person, a talent management and existing talent management systems in developed EU countries, that stress the importance to the public sector, the literature review of the existing foreign scientific literature and sources and the study of the national and international sources was made. To find out what are the legal limitations in the field of talent management in Slovenia, the study of the relevant legal resource in the field of labour law and civil servant law was done.

The paper sought answers to the following research questions:

(1) (How) are talented employees treated differently from other employees? If organisations are to make the most of their employees' capabilities, 
employees must be properly managed. Based on the analysis of literature and resources, we examined how organisations in general recognise and manage talented employees. The literature review of the foreign scientific literature and sources about the concept of the talented employees and talent management is presented in the third chapter.

(2) What types of models or practices in the field of talent management are applied in European countries? The literature review of the foreign scientific literature and sources about some indicated models or examples of different practices in the field of talent management in some European countries have been done. The summary of the existing literature about the different approaches to talent management in the public sector is presented in the fourth chapter.

(3) What are the legal limitations in the field of civil servant talent management in Slovenia? To answer the research question, the study of the relevant legal resource in the field of labour law and civil servant law in Slovenia has to be done. This particularly means the Employment Relationship Act, Public Employees Act and Public Sector Salary System Act as they present the legal framework of human resource management in the public sector. Based on the results of the study, the opportunities and obstacles for (special) treatment of talented civil servants in Slovenia were determined. The study is presented in the fifth chapter.

\section{Definition of the concept of talented people and talent management}

To answer the first research question (how) are talented employees treated differently from other employees? the literature review of the existing foreign scientific literature and sources about the concept of the talented employees and talent management is presented hereinafter in this chapter.

According to Dries (2013a), the concept of a talented person has different meanings for different people (e.g. researchers, organisations, HR professionals, employees) and it is hard to assess which one is more appropriate. In her research Tansley (2011) found out that "there is no single or contemporary definition of talent in any one language; there are different perspectives of talent." According to her explanation, "the meaning tends to be specific to an organisation and influenced by the nature of the work undertaken."

Zhengyuan and Gang (2011) claim that a talented person has expertise and specific skills, and contributes to the benefit of society with creative work. Petersone, Ketners, and Krastins (2014) define a talented person as highly skilled, well-educated, and prospective employee. Vural, Vardarlier, and Aykir (2012) argue that talent is partly innate and partly acquired through education, training, experience, and practice. Talent can be considered from the perspective of an individual or an organisation. In considering talent from the perspective of an individual, it is necessary to have an understanding of the current position of the employee in the organisation, and to determine where 
and how he/she wishes to be positioned in the future (i.e. career planning). From the perspective of an organisation, talent is related to the concept of "the right people in the right positions"; thus, talented people must perform tasks directed towards achieving organisational goals. Silzer and Church (2009) argue that consideration from the perspective of an individual's potential is directed to the opportunity open to individuals to become something more than what they currently are. According to Dries and Pepermans (2007), considering talented people from the perspective of performance is directed to the results already achieved, and not the inputs needed to achieve the result, as this is the case in the aforementioned perspectives. The authors argue that this is a more common way of identifying talented people in organisations, as it is easier to measure results. Gallardo-Gallardo et al. (2013) designed a framework for the conceptualization of a talent within the world of work, shown in figure 1.

Figure 1: Framework for the conceptualization of a talent within the world of work

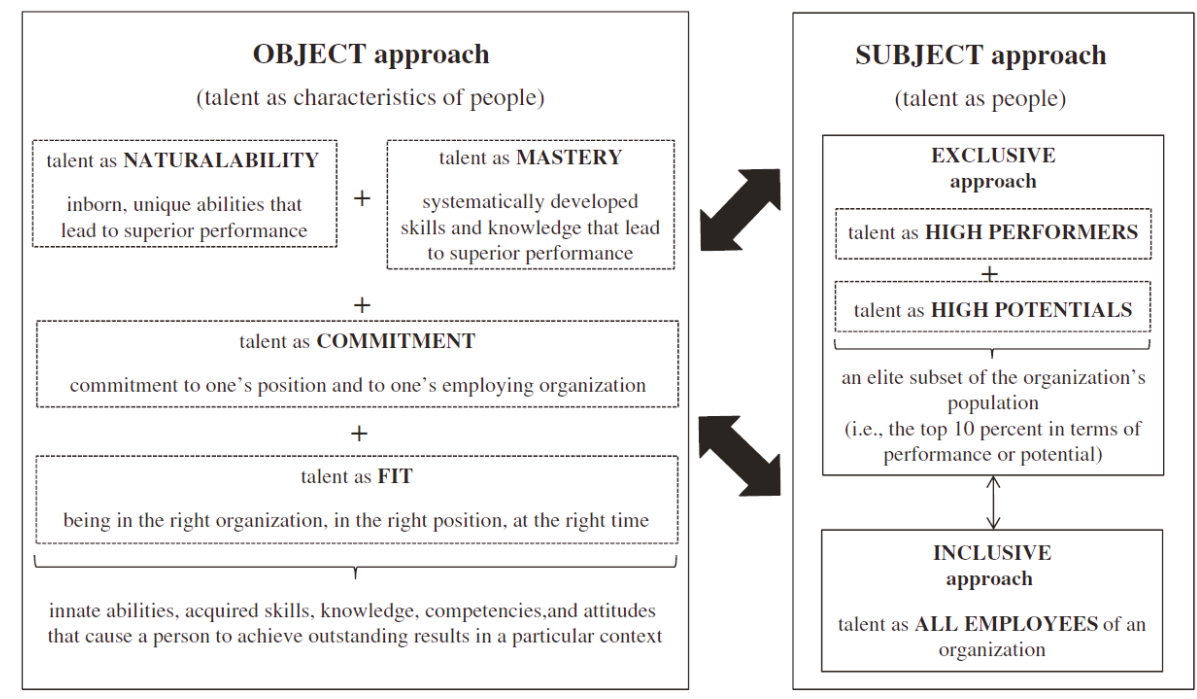

Source: Gallardo-Gallardo et al. (2013)

The term "talent" has different meanings, usually the reasons are different views and approaches by making a definition. From the human resources management view, the "framework for the conceptualization of a talent within the world of work" that Gallardo-Gallardo et al. (2013) designed, show the most relevant view by defining the term "talent". If the term "talent" is seen as an object, it presents different characteristics of people (abilities, skills, knowledge, competencies); that can be inborn or (systematically) developed; and people's attitudes to achieve the best results, that can be achieved if people are committed to the organisation and are employed in the right position at the right time. If the term "talent" is seen as a subject, it presents people (employees); dealing with "talents" as subjects is a part of talent management, which is explained below. 
According to Meyers et al. (2013) talent management should be understood as a scientific discipline that falls within the field of human resource management. Depending on the perspective from which the term is considered, Meyers et al. (2013) agrees that the field of talent management usually focuses only on certain employees who are subjected to specific practices laid down in the field of human resource management. Thunnissen and Van Arensbergen (2015, pp. 182-183) claim that there are "five dimensions of the definition of the talent management, namely (1) division along the subject (talent is a synonym for people) vs the object (talent is a synonym for characteristics of people) dimension (Gallardo-Gallardo et al., 2013); (2) division "between inclusive view of talent and talent management (related to all employees) and exclusive view (related to selective group of employees)" (Thunnissen and Van Arensbergen, 2015, pp. 182-183) - or, as argued by Buttiens and Hondeghem (2015), all employees are part of the talent management policy (the inclusive view) or only a segment of the employees is part of the talent management policy (the exclusive view) - or, as argued by Nijs et al. (2014) "each person has a set of strengths (the inclusive view) or certain group (talents) makes relative contribution (the exclusive view) (Thunnissen and Van Arensbergen, 2015, pp. 182-183); (3) division according to talent - whether it is innate and stable or it can be acquired and developed through training (Meyers et al., 2013); (4) division along the input (abilities and motivation) vs output (excellent performance and success) (Ross, 2013); (5) division according to the extent to which talent is conditional on its environment - is it transferable or context-depended (Dries, 2013b)" (Thunnissen and Van Arensbergen, 2015, pp. 182-183).

Buttiens and Hondeghem (2015) define talent management as a process aimed at attracting, developing, and retaining talent, which includes the perspective of both the employee and the organisation. The authors argue that when developing talent, the right context, support, and a proper fit with individual, societal, and organisational goals are necessary. Gadsen et. al (2017) define talent management as the proactive recognition and development of employees at all levels in the organisation, to help them reach their full potential at their workplace. Petersone et al. (2014) define talent management as a strategy, activities, tools, and processes that lead to the identification, motivation, retention, and development of talented employees, in order to effectively perform tasks in line with future needs and trends.

Lewis and Heckman (2006) argue that: (1) talent management is not essentially different from human resource management; namely, both involve getting the right job done at the right time and managing the supply, demand, and flow of people through the organisation; talent management also includes recruitment, selection, training, and appraisal; however, an important question is how to strategically handle talent; (2) talent management is integrated in human resource management with a selective focus; talent management may use the same tools as human resource management, but the focus is on a relatively small segment of the workforce, defined as "talented" by virtue of their current performance or future potential; talent management also involves staffing processes, but all focused on talented individuals only; (3) 
talent management is focused on developing competences by directing the "talent stream" within the organisation; the emphasis is therefore on "pipelines" rather than on "talent pools", which is closely linked to successful human resource planning, and focuses primarily on the permanence of talent; talent management is therefore the strategic management of the flow of talented employees through various roles and jobs within the organisation. According to Stahl et al. (2007), when deciding who to include in the talent pool in organisations, the most commonly used data comes from annual or bi-annual employee performance assessments. Mäkelä, Björkman, and Ehrnrooth (2010) emphasise that when including employees in the talent pool, other factors that affect the final decision in the talent recognition process should also be considered besides performance assessment. Fernández-Aráoz (2014) indicates the following criteria for determining highly talented employees:

- Motivation (a fierce commitment to excel in the pursuit of unselfish goals);

- Curiosity (a penchant for seeking out new experiences, knowledge, and candid feedback, and an openness to learning and change);

- Insight (the ability to gather and make sense of information and suggest new possibilities, solutions);

- Engagement (a knack for using emotion and logic to communicate and connect with people);

- Determination (the wherewithal to fight for difficult goals despite challenges and to confront challenges).

Vural et al. (2012) argue that talent management is to direct employees to their profession and expose and regulate their talents for it. The first step in the talent management process is to develop a strategy, whereby focus should be placed on key employees whose talent is needed to achieve strategic goals in the future. Managers should continuously improve the talents of employees, provide training, and ensure their satisfaction, and thus increase efficiency and competitiveness. Vladescu (2012) states that talent management has significant impact on recruiting the right people for the right jobs, in order to reach higher performance and to achieve the objectives; it involves maximising employee potential, promoting employee achievement, and investing in their development; it is aimed at improving efficiency, and reducing risks and costs. Mäkelä et al. (2010) argue that talent management is focused on a particular group of employees who rank at the top in terms of their abilities and efficiency, and therefore among potential managers either in the near or distant future. According to them, organisations usually combine a talent identification process with performance practices, and link them to decisions regarding investment in their education, training, development, additional benefits, and rewards.

According to Orrov et al. (2014), vertical and horizontal alignment is important for proper strategic talent management. Vertical alignment (strategic alignment) refers to the link between business needs and employee performance. Organisations should treat employees so as to enable them to de- 
velop relevant competences and stay motivated. It is necessary to ensure that employees act in a way that is of utmost importance for achieving the organisation's business strategy. Horizontal alignment (talent management system) refers to the implementation of various practices in the field of talent management, which are integrated in the entire employee management system of the organisation. Investing in strategically important talented employees guarantees the success of the organisation. Therefore, strategic talent management is not a reflection of business strategy, but rather, it should support the business strategy and ensure the talented employees who will enable the achievement of the organisation's business strategy.

The term "talent management", similar to the term "talent", has different meanings. Most previously mentioned definitions focus on two differences of the meaning the term "talent", that are explained in the "framework for the conceptualization of a talent within the world of work", which GallardoGallardo et al. (2013) designed. To sum, according to the "framework for the conceptualization of a talent within the world of work, "talents" in "talent management" are "people" and there are two different "approaches to talent management" in organisations (by planning, attracting, selection, introduction, developing, evaluation, rewarding, and promotion); namely exclusive approach that gives attention to an elite subset of the organisation's population - high performers and high potentials, and inclusive approach that gives attention to all employees of the organisation. To highlight the importance of talent management in the public sector, different talent management systems in developed EU countries, that stress the importance to the public sector, are shown below.

\section{Approaches to talent management in the public sector}

To answer the second research question, what types of models or practices in the field of talent management are applied in European countries? the summary of the existing foreign scientific literature and sources about the different approaches to talent management in the public sector is presented hereinafter in this chapter.

Vladescu (2012) highlights that the public sector is often faced with talent drain; therefore, according to her, talent management, as part of the human resource management, is one of the most important processes for achieving the success of organisations. Talent management should be harmonised with the organisation's strategy, ensure equal opportunities, and maintain diversity, notably based on the recognised performance and potential of employees. In the public sector, it is necessary to provide resources for employee development and to draw up a strategic plan with clearly defined goals. Public sector organisations should be aware of the necessity to have a precisely designed talent management system. The application of appropriate talent management software can be of assistance in different areas within the organisation: management, creation of "talent pools", performance assessment, education, career development, competences. A database of talented employees 
should be created in order to avoid the consequences of talent drain. It is necessary to set goals, hire the right people in the right job, and draw up plans and strategies to bridge future gaps. The concept of talent management in the public sector should be designed in such a way that it can be adapted and applied in different ways in all public sector organisations. Thunnissen and Buttiens (2017) have developed a conceptual model, based on institutional mechanisms and logic as well as the characteristics of public sector organisations, which explains how an organisation's environment affects the selection of an inclusive or exclusive approach to talent management.

Figure 2: Conceptual model for the selection of talent management approach

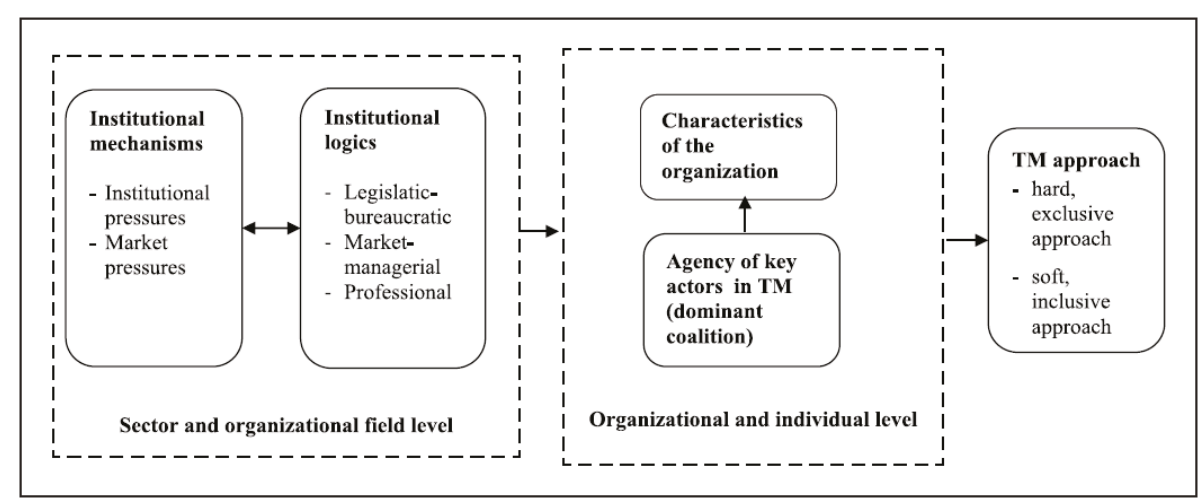

Source: Thunnissen and Buttiens (2017)

Petersone et al. (2014) emphasise that public sector talent management systems are important for the better functioning of the state, and are a key factor in the development of the public sector. The authors highlight the Estonian talent management model designed to provide mechanisms for attracting, retaining, and evaluating performance, and rewarding and training especially those employees who are recognised as talented. Two groups of talent are identified; namely, the "key positions" group (involved in strategy development) and the "strategic positions" group (working on strategy implementation). The job profile defines the jobs well, which makes it possible to identify "inclusive employees". Similarly, a "talent pool" is created, within which "strategic employees" are trained for "key positions". 
Figure 3: Key position identification scheme

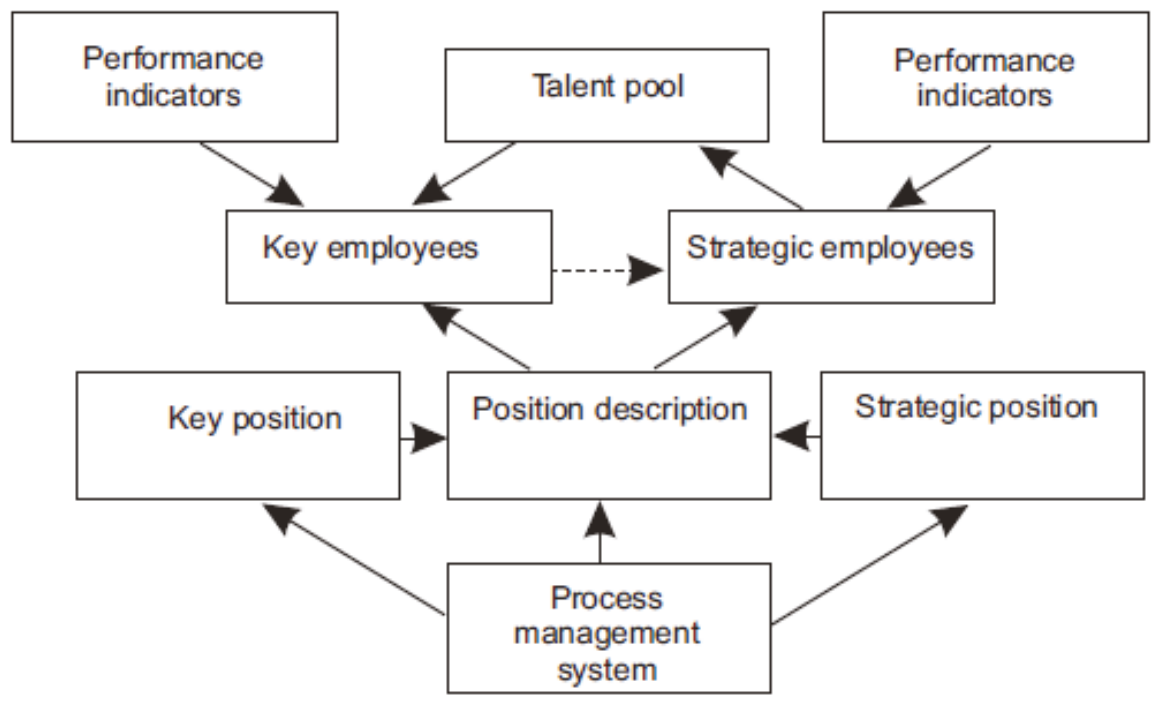

Source: Petersone et al. (2014)

The authors aimed to create a Latvian model based on the Estonian talent management model. Most Latvian state and local institutions have not yet introduced talent management models; therefore, they suggested that it is necessary to develop an integrated model that would be implemented together with other human resource management systems.

Figure 4: Integrated talent management model

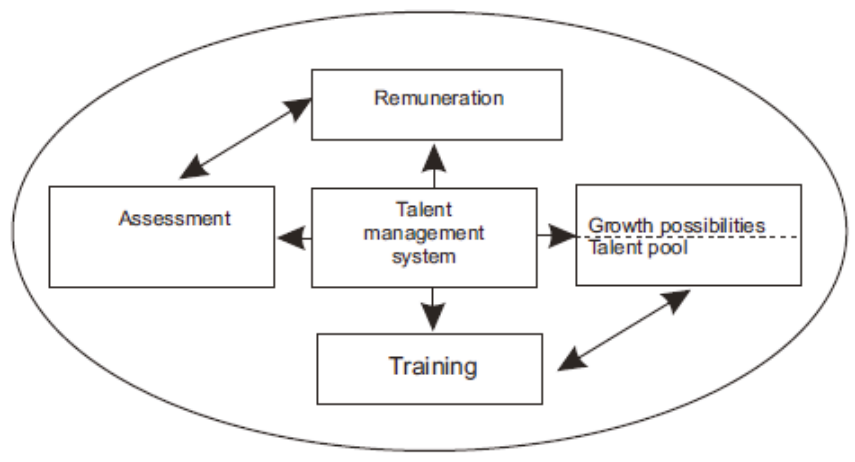

Source: Petersone et al. (2014)

An integrated talent management model enables the integration of different areas of human resource management, which ensures better efficiency, effectiveness, and leadership that enables the identification and development of talented employees. In contrast with the Estonian model, the authors suggest that "key employees" could be determined based on employee profiles that accurately specify the duties and capabilities of civil servants. They em- 
phasise that, in order to identify talent, it is important to be familiar with the capabilities of employees.

Gadsen et al. (2017) studied the area and approaches to talent management in the public sector in Scotland. They observed that a major obstacle in this area is an inadequate commonly agreed definition of "talent management", and that, consequently, approaches to talent management are both inclusive and exclusive. Based on the research, they created a checklist of the key issues which organisations need to consider when developing or reviewing an existing talent management strategy and approach.

Van den Broek et al. (2018) studied the "innovative inter-organisational talent pool" of four Dutch hospitals within the same geographical area (south of the Netherlands). They examined opinions on inter-organisational cooperation in the field of talent management based on structured interviews with top managers, line managers, staff experts, employee representatives, or members of the project team in the field of talent management of all four hospitals studied. The hospitals are competitive in terms of financial resources, job candidates, and patients; however, they co-operate inter-organisationally through the exchange of employees via a "talent pool". Namely, they have an education and training agreement for a specific number of employees per hospital, with the aim to increase the number of qualified employees available to the hospitals in their region. The agreement enabled the hospitals to create an innovative way of talent management that offers career development opportunities to training participants in hospitals that cooperate interorganisationally, and retain them in the "talent pool". In this way, hospitals endeavour to attract and retain more suitable candidates. It is expected that this will also reduce external employment costs. Developing inter-organisational cooperation and creating local "talent pools" are innovative strategies that help improve the performance of organisations. The "talent pool" is a virtual organisation (of medical and management staff), which operates at three levels. The first is a cooperating hospital, in which employees are exchanged within the organisation (hospital). The second is a virtual labour market between cooperating organisations (hospitals). The third level is an (external) labour market (when an employee from within the "talent pool" cannot fill a vacant post). The authors note that this is an opportunity for smaller organisations (e.g. nursing homes, IT organisations, etc.) that find it difficult to get talented employees; therefore, cooperation with other organisations, for example in the same region, is essential. Pools of talent for R\&D, knowledge sharing, and co-creation between organisations, regions, etc., can be created.

Ingram and Glod (2016) provide assessments of the state in the field of talent management in healthcare organisations in Poland. They observe that talent management programmes are not appreciated (not even in large organisations). Although there are no special talent management programmes, organisations know which employees are of crucial importance to their success, and therefore try to do their best to treat them differently; above all, they are focused primarily on training and motivation. The acquisition of additional skills, 
commitment, and motivation are expected benefits for employees classified as "talented". Less attention is being paid to job satisfaction and an overall understanding of an individual's well-being. The authors stresses, however, that organisations should focus their attention on developing a more strategic approach to talent management; programmes should focus on maintaining employee satisfaction; if the best employees are to be retained, their needs and goals must be taken into account and harmonised with the objectives of the organisation.

Buttiens and Hondeghem (2015) studied the development phase of talent management policies, approaches to talent management, and HR processes within the framework of talent management policies in Flemish government organisations. They observed that $20 \%$ of Flemish governmental organisations were developing a talent management strategy, and a quarter were implementing and evaluating talent management practices. More than half of the organisations under consideration apply an inclusive approach. Education and training, performance management, and commitment and engagement strategies, predominate in personnel processes within the framework of talent management policies; the least attention is paid to rewarding. Furthermore, they observe that talent management practices make it possible to meet the needs of employees, whereby organisational objectives can also be achieved.

Upon examining institutional mechanisms, institutional logic, and organisational characteristics, Thunnissen and Buttiens (2017) observe that Flemish (local) government organisations use an inclusive approach to talent management (management is targeted to all employees). The objective of organisations is to ensure the well-being of employees, which affects the well-being of organisations. Practices are focused on the performance and development of both employees and organisations. The external context affecting the fact that organisations apply an inclusive approach to talent management is associated with political pressure, notably focused on the principles of new public management; labour and employment regulations are strict; government organisations are in a weak position (therefore they are not "an attractive employer"); budgetary possibilities fail to attract new employees. The impact of the internal context or the characteristics of organisations, affecting the fact that organisations apply an inclusive approach to talent management, include strategy and task reforms, as well as needs for increased efficiency and flexibility; a large proportion of employees are permanently employed; an organisational culture of equality is also to be observed.

To sum, talent management depends on the sectors, organisations and people. For appropriate managing talents in the organisation, talent management must be part of the strategic human resources management. By (strategic) planning, attracting, selection, introduction, developing, evaluation, rewarding, and promotion, can in accordance with the "framework for the conceptualization of a talent within the world of work" (Gallardo-Gallardo et al., 2013), for dealing with "talents" (people) (so called talent management), inclusive and exclusive approach can be used, or as argued by Thunnissen and Buttiens 
(2017) the "hard" approach, where the interests of the organisation outweigh the interests of the employees, and in the "soft" approach, where the interests of the employees are as important as the interests of the organisation.

\section{Legal perspectives of talent management in public administration}

To answer the third research question, what are the legal limitations in the field of civil servant talent management in Slovenia? the study of the relevant legal resource in the field of labour law and civil servant law is presented hereinafter in this chapter.

Regulation plays an important role in exploring talent management in the public sector, since the employment status of civil servants is legally significantly more defined and limited, compared to the private sector. The authors observe that regulation in the private sector significantly limits the potential for employee rewards (Franca, 2007; IMAD, 2018). However, in the public sector, this represents an additional significant limitation, since the creation of a development strategy and talent retention may only be created within statutory provisions. Within the framework of the research, an analysis of the Slovenian arrangement was carried out, which serves an example of regulation of civil servant relations and, within this, the options of talent management system creation.

To start with, it is of major importance to take into account one of the fundamental principles of labour and civil servant law; namely, the principle of equality, as laid down in the Employment Relationship Act. ${ }^{1}$ The employer is to ensure equal treatment with regard to personal circumstances in employment, promotion, training, education and other rights from the employment relationship. Furthermore, Article seven of the Public Employees Act (hereinafter referred to as the PEA) ${ }^{2}$ stipulates that the recruitment of civil servants is to be carried out so as to ensure equal accessibility to posts to all candidates on equal terms, and the selection of a candidate who is best qualified to carry out the post-related tasks. This implies a fundamental obligation to establish a talent management system in the public sector in such a way that all civil servants have the opportunity to participate, or the possibility to be included, and that the criteria for the (non) inclusion of an individual civil servant should not be discriminatory, but objective and work-related. At baseline, this may be contrary to the talent management system, because identification of a specific trait in talented people plays a key role that may not be immediately confirmed and verified with results, but may involve the potential for development, which is to be assessed upon employment. From a legal aspect, this can pose a considerable risk of unequal treatment, which is not in line with the fundamental principles of labour and civil servant law. Therefore, it would be more appropriate to identify an individual in the public sector as talented after a certain period of time, when he/she already shows tangible results

1 Official Gazette of the Republic of Slovenia No. 21/13, 78/13, 33/16, 52/16, 15/17, 22/19, $81 / 19$.

2 Official Gazette of the Republic of Slovenia No. 63/07, 65/08, 69/08, 40/12. 
based on which he/she is believed to be more professional and/or more effective than others. For example, the Establishment of a Civil Service Competency Model project (MPA, 2020), which lays down competences for groups of posts in public administration, establishes a competence assessment/identification system, and a required employee competence maintenance/upgrade system, is primarily focused on those who are already employed in the state administration, and not on the candidates for employment.

Moreover, the talent management system also requires the creation of financial assets for running the system, and for appropriate training. Generally, more funds are devoted to talented employees, which stirs up a problem of unequal treatment of civil servants. In employment relationship, education and training are a right and an obligation of both the employee and the employer (Employment Relationship Act, Article 170); however, in the civil service system, rights should not be ensured to a greater extent than is provided for by law, implementing regulation or collective agreement, if this is to the burden of public resources (PEA, Article 16). How to ensure equal access to education and training to all civil servants and a specifically adapted system for talent development, can be a problem in practice. One of the possible solutions is a properly designed bonus system, which is on the one hand thoroughly defined for the public sector with the Public Sector Salary System Act (hereinafter referred to as the PSSSA), ${ }^{3}$ but on the other hand opens up opportunities to numerous anomalies (Vidič, 2018), and leaves little scope for autonomy management. Performance bonus systems and the possibility to pay additional awards for special accomplishments are essential for the proper development of talented people and their retention in the public sector. However, this creates several obstacles from a legal point of view. It cannot be disputed that a performance bonus system is one of the key aspects of proper management, not only for the talented, but for the employees in general. Nevertheless, this is not pursued in the civil servant system in Slovenia. Performance bonuses have been frozen for many years, although Article 17 of the PSSSA provides for performance-related bonuses for civil servants. This is due to many factors, including austerity measures during the economic and financial downturn, as well as the fact that unions in the public sector are increasingly engaged in raising basic salaries, rather than in the proper establishment of a performance bonus system. In general, social dialogue in the public sector is underdeveloped, and its ability to make such arrangements is questionable (Počivavšek, 2015). Another major obstacle is the promotion prospects for civil servants, which, pursuant to Article 16 of the PSSSA, is linked to three consecutive above-average annual grades. Taking into consideration the nonpayment of performance bonuses and the civil servants' desire for promotion (and thus a higher salary), the assessment system is fully undermined. Managers tend to succumb to the pressure exerted by civil servants; furthermore, in order to ease the work environment management, most civil servants are assessed as above average or excellent (Pečarič, 2014; Pečarič, 2019). This would imply that all civil servants are talented, which certainly fails to constitute a

3 Official Gazette of the Republic of Slovenia No. 108/09 - 84/18. 
solid basis for the proper development of the talent development system, as argued in this paper. Moreover, it is necessary to take into account that the promotion of civil servants (and thus talented) is not only financially but also hierarchically limited; for example, pursuant to Article 16 of the PSSSA, a civil servant may be promoted a maximum of ten salary grades. Civil servants who perform work in legal and organisational forms, e.g. institutions, that can raise additional funds in the market, are in a slightly better position. Although their use of funds is also under the review of the authorities, there is still enough room for the creation of an employee management system.

Therefore, if we are to develop an appropriate talented employee management system, an appropriate legal framework would be a prerequisite. However, it is not advisable to leave too much discretion to the management, since the position of civil servants cannot be equated with employees in the private sector (Korpič-Horvat, 2014).

From a legal point of view, it would be relatively inadmissible to characterise a person as talented upon his/her arrival, as this would immediately put him/her in a better, more favourable position compared to others. It would be less controversial to do so after a certain period, e.g. after a few months, as is usually the case with traineeship and/or a probationary period. In practice talent management in the Slovenian public sector would be difficult to develop without some proper legislative changes. Especially, more flexible options for rewarding and promoting more successful civil servants should be considered. As regards for the current practices our conclusion is that the existing system does not offer much possibilities for management to develop talent management.

\section{Discussion and conclusion}

Within the survey, we examined: (1) (How) are talented employees treated differently from other employees? Based on the summary of literature and resources, we established that organisations which are aware of the importance and contribution to the ultimate organisational objectives, treat talented employees differently from other employees in the organisation. In continuation from the analysis, we examined (2) What types of models or practices in the field of talent management are applied in European countries? Based on the summary of the existing literature and resources, we established that models or practices in the field of talent management widely vary in different European countries. Talent management is largely regulated as part of the tasks of employee management in organisations; however, there is a case of talent management that is regulated between organisations engaged in the same activity at local level (the case of Dutch hospitals in the south of the country).

If organisations are to make the most of their employees' potential, the employees must be properly managed. The talent management system should be strategically formulated, and integrated into the employee management system. It should therefore include all personnel processes (planning, attracting, selection, introduction, developing, evaluation, rewarding, and promo- 
tion), with a special emphasis on employees who are recognised as talented. In order to achieve this, talented individuals must first be recognised; therefore, the capacities of all employees should be considered. From the perspective of talented individuals, it is necessary to ensure that the "talented become the best they can", i.e. to have/develop the best capacities (competences). However, from an organisational point of view, it is necessary to ensure that talented employees perform tasks that significantly contribute to the realisation of organisational objectives. As argued by Petersone et al. (2014), employee profiles should accurately specify the duties and capabilities of talented civil servants.

Employees which the organisation recognises as talented, should be classified in the so-called "talent pool". Based on the literature review, it has been determined that the criteria for the classification of employees in a "talent pool" differs, and that besides achieving the capacities described in the formulated talent profiles (Petersone et al., 2014), (achieving) employee performance, as indicated by Stahl et al. (2007) and Mäkelä, Björkman, and Ehrnrooth (2010), other factors should also be considered, within which Fernández-Aráoz (2014) refers in particular to the "soft skills of the talented", encompassing high motivation, curiosity, ability to formulate solutions, cooperation, and persistence.

According to Altınöz, Çakıroğlu, and Çöp (2013) the process of talent management follows the steps listed in the continuation; particularly, (1) the identification of the objectives and strategy (answer to "where" and "how"), (2) the identification of key positions, (3) the identification of the profile of the talented (ideal employees - knowledge, skills, ability, experience, interest, focus on results), (4) the identification of potential (internal and external candidates), (5) the analysis of the gaps in the talented (determination of possible development and required training), (6) the drawing up and implementation of development plans (training, mentoring, etc.), (7) the assessment of candidate success (stay in or leave the talent pool), (8) the process of assessment and promotion of the talented (within the talent pool).

Legal regulation in the public sector is greater than in the private sector, and significantly affects employee management; therefore, we sought the answer to the third research question, what are the legal limitations in the field of civil servant talent management in Slovenia? The first limitation is strict observance of the principle of equality, and thus equal opportunities for inclusion in the system of talented civil servants. In this respect, the time of recruitment, which calls into question the assessment of potential, as a factor for inclusion in the employee management system upon the existing legislation, is critical. The applicable legislation in Slovenia places professionalism and achievements at the core of the distinction between civil servants, and not the potential itself, which may or may not be realised in practice. Therefore, it is more appropriate, from a legal point of view, to include civil servants in the system of talented individuals after a certain period of employment, when they have demonstrated above-average results in practice. The second major limitation is related to limited reward opportunities, and consequently, the 
promotion of civil servants. Currently, the applicable system is more obstructive than encouraging to the options of retaining talented employees; therefore, this would undoubtedly be the first step in the legislation amendment. Without proper rewards and other incentives, which the management could have, it is impossible to imagine a well-functioning talent management system. Thus good practices cannot be forms unless the legislative framework does not change. 


\section{References}

Altınöz, M., Çakıroğlu, D. and Çöp, S. (2013). Effects of Talent Management on Organizational Trust: A Field Study. Procedia - Social and Behavioral Sciences, 99, pp. 843-851.

Björkman, I. et al. (2013). Talent or Not? Employee Reactions to Talent Identification. Human Resource Management, 52(2), pp. 195-214.

Buttiens, D. and Hondeghem, A. (2015). Strategic choices regarding talent management in the Flemish public sector. Society and Economy, 37(1), pp. 49-72.

Collings, D. G. (2014). Integrating global mobility and global talent management: Exploring the challenges and strategic opportunities. Journal of World Business, 49(2), pp. 253-261.

Dries, N. (2013a). Talent management, from phenomenon to theory: Introduction to the Special Issue. Human Resource Management Review, 23(4), pp. 267-271.

Dries, N. (2013b). The psychology of talent management: A review and research agenda. Human Resource Management Review, 23(4), pp. 272-285.

Dries, N. and Pepermans, R. (2008). 'Real' high potential careers: An empirical study into the perspectives of organisations and high potentials. Personnel Review, 37(1), pp. 85-108.

Dries, N. and Pepermans, R. (2007). Using emotional intelligence to identify high potential: A metacompetency perspective. Leadership \& Organization Development Journal, 28(8), pp. 749-770.

FernáNdez-AráOz, C. (2014). 21 $1^{\text {st }}$ Century Talent Spotting. (cover story). Harvard Business Review, 92(6), pp. 46-56.

Franca, V. (2007). Flexible working relationships: Legal Foundations and Human Resources Management. (Prožno delovno razmerje: pravni temelji in ravnanje s človeškimi viri). Podjetje in delo, 33(2), pp. 399-419.

Gadsden, S. et al. (2017). Talent Management in Public Services in Scotland. Improvement Service, Edinburgh Napier University, University of the West of Scotland School of Business and Enterprise. At <http://www. improvementservice.org.uk/documents/research/talent-management-finalreport.pdf> accessed 29 October 2019.

Gallardo-Gallardo, E., Dries, N., and González-Cruz, T. F. (2013). What is the meaning of 'talent' in the world of work? Human Resource Management Review, 23(4), pp. 290-300.

Gelens, J. et al. (2013). The role of perceived organizational justice in shaping the outcomes of talent management: A research agenda. Human Resource Management Review, 23(4), pp. 341-353.

Glenn, T. (2012). The state of talent management in Canada's public sector. Canadian Public Administration, 55(1), pp. 25-51.

Ingram, T. and Glod, W. (2016). Talent Management in Healthcare Organizations-Qualitative Research Results. Procedia Economics and Finance, 39, pp. 339-346.

Korpič-Horvat, E. (2014). Is the position of a public servant different from an employee in private sector through the aspect of working relationship? (Ali je položaj javnega uslužbenca drugačen od položaja delavca skozi vidik delovnega razmerja)? Delavci in delodajalci, 14(2/3), pp. 235-252.

Lewis, R. E. and Heckman, R. J. (2006). Talent management: A critical review. Human Resource Management Review, 16(2), pp. 139-154. 
Mäkelä, K., Björkman, I., and Ehrnrooth, M. (2010). How do MNCs establish their talent pools? Influences on individuals' likelihood of being labeled as talent. Journal of World Business, 45(2), pp. 134-142.

Meyers, M. C., van Woerkom, M., and Dries, N. (2013). Talent — Innate or acquired? Theoretical considerations and their implications for talent management. Human Resource Management Review, 23(4), pp. 305-321.

Ministrstvo za javno upravo (MJU). Establishing a competency model. (Vzpostavitev kompetenčnega modela). At <https://www.gov.si/zbirke/ projekti-in-programi/projekt-vzpostavitev-kompetencnega-modela/>, accessed 2 April 2020.

Nijs, S. et al. (2014). A multidisciplinary review into the definition, operationalization, and measurement of talent. Journal of World Business, 49(2), pp. 180-191.

Orr, E. J. (ed.) et al. (2014). Talent management best practice series. Strategic Alignment. The Korn Ferry Institute. At <http://static.kornferry.com/media/ sidebar_downloads/Best-Practices-Strategic_Alignment.pdf>, accessed 16 December 2019.

Pečarič, M. (2014). Representative Public Administration as the Modelling Behaviour for the New Bureaucracy. Central European Public Administration Review, 11(1), pp. 51-79.

Pečarič, M. (2019). Slovenian Civil Servants: "almost everyone is excellent" (Slovenski javni uslužbenci: "skoraj vsi so odlični"). Pravna praksa, 38(21/22), pp. II-VIII.

Petersone, M., Ketners, K. and Krastins, A. V. (2014). Talent Management in Public Administration Institutions: The Case Of Latvian Customs. The 8th International Scientific Conference 'Business and Management 2014'. Presented at the 8th International Scientific Conference 'Business and Management 2014', Vilnius, Lithuania.

Počivavšek, J. K. (2015). New social agreement and other issues of social dialogue in practice. (Nov socialni sporazum in druga vprašanja socialnega dialoga v praksi). Delavci in delodajalci, 15(2/3), pp. 351-365.

Ross, S. (2013). How definitions of talent suppress talent management. Industrial and Commercial Training, 45(3), pp. 166-170.

Silzer, R. and Church, A. H. (2009). The Pearls and Perils of Identifying Potential. Industrial and Organizational Psychology, 2(4), pp. 377-412.

Stahl, G. K. et al. (2007). Global Talent Management: How Leading Multinationals Build and Sustain Their Talent Pipeline. INSEAD Working Papers Collection, 34, pp. 1-36.

Tansley, C. (2011). What do we mean by the term "talent" in talent management? Industrial and Commercial Training, 43(5), pp. 266-274.

Tansley, C. and Tietze, S. (2013). Rites of passage through talent management progression stages: An identity work perspective. The International Journal of Human Resource Management, 24(9), pp. 1799-1815.

Thunnissen, M. and Van Arensbergen, P. (2015). A multi-dimensional approach to talent: An empirical analysis of the definition of talent in Dutch academia. Personnel Review, 44(2), pp. 182-199.

Thunnissen, M. and Buttiens, D. (2017). Talent Management in Public Sector Organizations: A Study on the Impact of Contextual Factors on the TM Approach in Flemish and Dutch Public Sector Organizations. Public Personnel Management, 46(4), pp. 391-418. 
Van den Broek, J., Boselie, P. and Paauwe, J. (2018). Cooperative innovation through a talent management pool: A qualitative study on coopetition in healthcare. European Management Journal, 36(1), pp. 135-144.

UMAR. (2018). Economic Challenges. (Ekonomski izzivi). Ljubljana: Erograf, d.o.o. At < https://www.umar.gov.si/fileadmin/user_upload/publikacije/izzivi/2018/ El_2018.pdf>, accessed 5. April 2020

Vidič, B. 2018. Systemic shortcomings of the public sector wage system.

(Sistemske pomanjkljivosti plačnega sistema javnega sektorja). Pravna praksa, 37(33), pp. II-VII.

Vladescu, A. (2012). The possibility of implementing talent management in the public sector. Management \& Marketing Challenges for the Knowledge Society, 7(2), pp. 351-362.

Vural, Y., Vardarlier, P. and Aykir, A. (2012). The Effects of Using Talent Management with Performance Evaluation System Over Employee Commitment. Procedia - Social and Behavioral Sciences, 58, pp. 340-349.

Zhengyuan, J. and Gang, Z. (2011). Research on the talent management from the perspective of systematic thinking of complex scientific management. Proceeding of the International Conference on E-Education. Entertainment and e-Management, pp. 261-265. 